\title{
CBLC Gene
}

National Cancer Institute

\section{Source}

National Cancer Institute. CBLC Gene. NCI Thesaurus. Code C97439.

This gene is involved in both ubiquitination and signaling. 